\title{
Influence of Panchagavya, Vermiwash and Organic Manure on Growth and Yield of Cauliflower (Brassica oleracea L. var. botrytis) cv. Pusa Snowball- 2
}

\author{
Ashok Pal and Shashi Bala* \\ Department of Horticulture, Udai Pratap College, Varanasi (U.P.), India \\ *Corresponding author
}

\section{A B S T R A C T}

\begin{tabular}{l} 
Ke y w o r d s \\
Panchagavya, \\
Vermiwash, \\
Organic manure \\
(FYM), \\
Cauliflower, \\
Growth and Yield. \\
\hline Article Info \\
Accepted: \\
15 July 2020 \\
Available Online: \\
10 August 2020
\end{tabular}

The present investigation was carried out during winter season of 2018-19 at Experimental Farm, Department of Horticulture, Udai Pratap Autonomous College, Varanasi (U.P.) in Randomized Block Design with three replications. Different combinations of Panchgavya, Vermiwash and organic manure (FYM) with control were used as treatment. Observations were recorded on vegetative, reproductive and yield related parameters. On the basis of recorded observations, it is found that the performance of the $\mathrm{T}_{5}(100 \%$ NPK through FYM @ 20 t/ha + foliar spray of Panchagavya @ 4\%) was better in all growth parameters such as plant height $(19.49,31.20$ and $39.23 \mathrm{~cm})$, number of leaves per plant $(9.37,15.87$ and 19.75), leaf area $\left(220.35,358.52\right.$ and $\left.518.25 \mathrm{~cm}^{2}\right)$, leaf length $(12.50,19.60$ and 19.90 $\mathrm{cm}$ )and stem length $(6.50,8.89$ and $10.78 \mathrm{~cm})$, while the performance of $\mathrm{T}_{6}[100 \% \mathrm{NPK}$ through Vermiwash (1:5 times dilution) + foliar spray of Panchagavya @ 4\%] was found significant influence on Days of curd initiation (63.69 days) and Days of curd maturity (74.09 days) at 30, 45 and 60 DAT. The values for the characters Diameter of curd (12.07 $\mathrm{cm})$, Weight of curd (737.78 g), Curd yield per plot $(11.77 \mathrm{~kg})$, Curd yield per hectare $\left(273.57\right.$ q) showed highly significant performance with $\mathrm{T}_{6}[100 \%$ NPK through Vermiwash (1:5 times dilution) + foliar spray of Panchagavya @ 4\%]. The treatment $\mathrm{T}_{5}$ (100\% NPK through FYM @ 20 t/ha + foliar spray of Panchagavya @ 4\%) performed as the best combination for growth and $\mathrm{T}_{6}[100 \%$ NPK through Vermiwash (1:5 times dilution) + foliar spray of Panchagavya @ 4\%] for reproductive and yield characters for commercial production of cauliflower.

\section{Introduction}

Cauliflower (Brassica oleracea L. var. botrytis) is an herbaceous annual or biennial vegetable of the family Crucifareae grown for edible tender curds and it is one of the popular vegetable crop around the world with respect to area, production and its availability. It has diploid chromosome number of $2 \mathrm{n}=2 \mathrm{x}=18$. Cauliflower is primarily grown for consumption as a vegetable eaten after bowel or steaming or drying as pickling. India is a second leading cauliflower producing country after China. India rank second in area and production of cauliflower in the world after China. In India, Cauliflower is grown in an area of 0.453 million hectare with production of 8.668 million tonnes and productivity of 19.8 metric tonnes per hectare. In Uttar Pradesh, it is grown in an area of 14.39 
thousand hectares with a production of 281.92 thousand tonnes per hectare (Anonymous, 2018). In the coming years the great challenges facing by the Nation is to provide safe food for the growing population in the country. In this regard, organic forming which is an eco-friendly and holistic production management system for promoting and enhancing the health of agro-ecosystem and ensure safe food for human consumption. Panchagavya has got reference in the scripts of Vedas (divine scripts of Indian wisdom) and Vrikshayurveda (Natarajan, 2002).

Panchagavya is reported to contain biofertilizers like Azospirillum, Azotobactor, Phosphobacteria, Pseudomonas and Lactobacillus (Yadav and Lourduraj, 2003). The essential plant nutrients from Panchagavya, Vermiwash and organic manure caused a tremendous influence on the growth, reproduction and yield of the crop.

\section{Preparation of Panchagavya, Vermiwash and organic manure}

Panchagavya is a pure organic formulation, in Sanskrit, means the mixed liquid of five by products obtained from cow such as cow dung, urine, curd, ghee and milk (all from cow). In India, use of Panchagavya in organic farming is gaining popularity in recent years especially in states like Tamil Nadu and Kerala. Panchagavya requires mainly five products of cow along with certain other ingredients as listed asFresh cow dung- $7 \mathrm{~kg}$; Cow urine- 3L; Cow milk- 2 L; Cow curd- 1 $\mathrm{kg}$, Cow ghee- $1 \mathrm{~kg}$; Sugarcane juice- $3 \mathrm{~L}$ or 500 g jaggary; Tender coconut water- $3 \mathrm{~L}$; Ripened banana- 12 Nos.; $100 \mathrm{~g}$ yeast $+100 \mathrm{~g}$ jaggary dissolved in $2 \mathrm{~L}$ of warm water (Natarajan, 2002; Pathak, 2002);. Firstly mixed the cow dung and ghee stirring along with ripe banana properly for 2-3 days carefully morning and evening three days after mixed all ingredients and stir carefully two times in day for 21-25 days (Natrajan, 2002).

Vermiwash is a liquid that is obtained after the passage of water through a column of worm action. It is a collection of excretory products and mucous secretion of earthworms along with micronutrients from the soil organic molecules. All available litter and refuse is mixed with soil and spread in the shed of animal so as to absorb urine. The next morning, urine soaked refuse along with dung is collected and placed in the trench. Trench size is 6-7.5 m length, 1.5-2.0 m width and $1.0 \mathrm{~m}$ deep are dug. A section of the trench from one end should be taken up for filling with daily collection. When the section is filled up to a height of 45 to $60 \mathrm{~cm}$ above the ground level, the top of the heap is made into a dome and plastered with cow dung earth slurry. The manure is ready for use in about four to five month after plastering.

\section{Materials and Methods}

The experimental material for the present investigation was comprised of a standard variety Pusa Snowball-2 and treated with different combinations of Panchagavya, Vermiwash and organic manure at different interval and replicated thrice in Randomized Block Design. The experiment was carried out at Experimental Farm, Department of Horticulture, Udai Pratap College, Varanasi (U.P.), during Rabi season of 2018-19. The whole investigation was conducted under the scientific management practices. During study, observations for growth parameters such as Plant height $(\mathrm{cm})$, Number of leaves per plant, Leaf length $(\mathrm{cm})$, Leaf area $\left(\mathrm{cm}^{2}\right)$, Stem length $(\mathrm{cm})$, reproductive parameters like Days to first curd appearance, Days to curd maturity and yield parameters such as Diameter of curd $(\mathrm{cm})$ Weight of curd $(\mathrm{g})$, Curd yield (Kg/plot) and Yield per hectare (q) were recorded on five randomly selected plants from each treatment. 
The different treatments used are $\mathrm{T}_{1}(100 \%$ NPK through FYM @ 20 t/ha), T2 (100\% NPK through Vermiwash (1:5 time dilution)), $\mathrm{T}_{3}(100 \%$ NPK through FYM @ 20 t/ha + foliar spray of Panchagavya @ 2\%), $\mathrm{T}_{4}$ (100\% NPK through Vermiwash (1:5 time dilution) + foliar spray of Panchagavya @ $2 \%), \mathrm{T}_{5}(100 \%$ NPK through FYM @ 20 t/ha + foliar spray of Panchagavya @ 4\%), $\mathrm{T}_{6}$ (100\% NPK through Vermiwash (1:5time dilution) + foliar spray of Panchagavya @ 4\%), $\mathrm{T}_{7}$ (Foliar spray of Panchagavya @ 4\%), $\mathrm{T}_{8}$ (100\% NPK through FYM @ 20 t/ha + Vermiwash (1:5 time dilution)) and $\mathrm{T}_{9}$ (Control). The data recorded from experiment for eleven characters in cauliflower cv. Pusa Snowball- 2 with different treatments was subjected to the following statistical analysis as per procedure described by Gomez and Gomez (1984). The significance of the treatments was tested through F-test at 5\% and $2 \%$ level of significance. Whereas, the mean analysis was done after testing the significance of the variance ratio of error mean squares.

\section{Results and Discussion}

The application of Treatment $\mathrm{T}_{5}(100 \%$ NPK through FYM @ 20 t/ha + foliar spray of Panchagavya @ 4\%) was showed the maximum plant height showed in fig. 1 and table 1, number of leaves and leaf area significantly. The use of Panchagavya, Vermiwash with Organic Manure significantly improve the growth of cauliflower crop in comparison to chemical fertilizers alone. The leaf length was significantly increased with the application of Panchagavya, Vermiwash and Organic Manure.

The maximum leaf area was observed in Treatment $\mathrm{T}_{5}(100 \%$ NPK through FYM @ 20 t/ha + foliar spray of Panchagavya @ 4\%) during 2018-19 in Rabi season. Similar types of results are recorded in various crops likes brinjal, chilli, chick pea, moringa okra etc. by various researchers likes Velmurugan et al., (2008), and Kanomozhi (2004).

The Panchagavya, Vermiwash and Organic Manure were showed very well effect on curd diameter, curd weight and yield of cauliflower respectively. The maximum curd diameter, curd weight and curd yield were reported and showed in figure 6,7 and table 2 with the application of Treatment $\mathrm{T}_{6}(100 \%$ NPK through Vermiwash (1:5 times dilution) + foliar spray of Panchagavya @ 4\%). Simultaneous types of results are also found in different crops by various researchers likes Lalitha et al., (2000), Kanwar et al., (2002), Velmurugan (2005), Gorge (2006) and Ali et al., (2011).

Presence of macro (N, P, K and $\mathrm{Ca}$ ) and micro ( $\mathrm{Zn}, \mathrm{Fe}, \mathrm{Cu}$ andMn) nutrients besides total reducing sugars (glucose) in Panchagavya. Chemolithotrops and autotropic nitrifiers (ammonifers and nitrifers) present in Panchagavya which colonize in the leaves increased the ammonia uptake and enhance the total N supply Papen et al., (2002), Swaminathan,et al., (2007). The $\mathrm{pH}$ of Panchagavya was lowered to 4.52 at 30 days of fermentation and this might be due to Lactobacillus bacteria in Panchagavya, which produced more organic acids during fermentation (Mathivanan et al., (2006).

The use of Panchagavya, Vermiwash with Organic Manure significantly improve the growth of cauliflower crop in comparison to chemical fertilizers alone.

The result obtained by the use of FYM with Panchagavya are due to rapid cell division, multiplication and cell elongation in meristematic region of plant which promoted vegetative growth of plant in the form of plant height, number of leaves and leaf area (Fig.19). 
Table.1 Effect of Panchagavya, Vermiwash and organic manure on growth, reproduction and yield

\begin{tabular}{|c|c|c|c|c|c|c|c|c|c|c|c|c|c|c|c|}
\hline \multirow[t]{2}{*}{ Treatments } & \multicolumn{3}{|c|}{ Plant height (cm) } & \multicolumn{3}{|c|}{ Number of leaves/plant } & \multicolumn{3}{|c|}{ Stem length $(\mathrm{cm})$} & \multicolumn{3}{|c|}{ Leaf length $(\mathrm{cm})$} & \multicolumn{3}{|c|}{ Leaf area $\left(\mathrm{cm}^{2}\right)$} \\
\hline & $\begin{array}{c}\text { 30 } \\
\text { DAT }\end{array}$ & $\begin{array}{c}45 \\
\text { DAT }\end{array}$ & $\begin{array}{c}60 \\
\text { DAT }\end{array}$ & $\begin{array}{c}\text { 30 } \\
\text { DAT }\end{array}$ & $\begin{array}{c}45 \\
\text { DAT }\end{array}$ & $\begin{array}{c}\text { 60 } \\
\text { DAT }\end{array}$ & $\begin{array}{c}30 \\
\text { DAT }\end{array}$ & $\begin{array}{c}45 \\
\text { DAT }\end{array}$ & $\begin{array}{c}60 \\
\text { DAT }\end{array}$ & $\begin{array}{c}\text { 30 } \\
\text { DAT }\end{array}$ & $\begin{array}{c}45 \\
\text { DAT }\end{array}$ & $\begin{array}{c}\text { 60 } \\
\text { DAT }\end{array}$ & $\begin{array}{c}\text { 30 } \\
\text { DAT }\end{array}$ & $\begin{array}{c}45 \\
\text { DAT }\end{array}$ & $\begin{array}{c}\text { 60 } \\
\text { DAT }\end{array}$ \\
\hline $\mathbf{T}_{1}$ & 18.00 & 28.04 & 37.80 & 7.92 & 13.68 & 18.33 & 5.00 & 6.29 & 9.10 & 10.54 & 16.52 & 17.70 & 182.60 & 290.63 & 453.32 \\
\hline $\mathbf{T}_{2}$ & 17.10 & 26.98 & 35.79 & 6.53 & 12.26 & 16.57 & 4.90 & 6.33 & 9.22 & 9.98 & 18.11 & 18.77 & 151.47 & 258.41 & 410.44 \\
\hline $\mathbf{T}_{3}$ & 15.60 & 24.10 & 33.88 & 7.60 & 13.37 & 17.67 & 5.11 & 6.99 & 9.67 & 11.10 & 17.00 & 18.11 & 191.31 & 318.46 & 468.60 \\
\hline $\mathbf{T}_{4}$ & 17.70 & 27.59 & 36.00 & 7.21 & 12.82 & 17.37 & 5.43 & 6.75 & 8.97 & 12.12 & 18.28 & 18.79 & 173.30 & 295.44 & 437.09 \\
\hline $\mathbf{T}_{5}$ & 19.49 & 31.20 & 39.23 & 9.37 & 15.87 & 19.75 & 6.50 & 8.89 & 10.78 & 12.50 & 19.60 & 19.90 & 220.35 & 358.52 & 518.25 \\
\hline $\mathbf{T}_{6}$ & 18.73 & 29.98 & 37.45 & 8.73 & 15.30 & 19.29 & 6.12 & 8.48 & 10.21 & 11.76 & 17.57 & 17.99 & 210.60 & 345.68 & 501.57 \\
\hline $\mathbf{T}_{7}$ & 16.90 & 25.89 & 36.00 & 6.87 & 12.50 & 16.81 & 5.38 & 7.43 & 9.87 & 10.10 & 16.98 & 18.56 & 162.96 & 276.31 & 421.25 \\
\hline $\mathbf{T}_{8}$ & 18.10 & 29.00 & 37.95 & 8.20 & 14.31 & 18.64 & 5.99 & 7.22 & 9.98 & 11.83 & 17.00 & 18.11 & 201.43 & 332.19 & 481.84 \\
\hline $\mathbf{T}_{9}$ & 14.98 & 23.88 & 33.89 & 6.13 & 11.77 & 16.32 & 4.89 & 6.00 & 9.00 & 8.99 & 16.00 & 17.66 & 147.83 & 243.09 & 390.81 \\
\hline SEm \pm & 0.22 & 0.24 & 0.29 & 0.28 & 0.19 & 0.22 & 0.13 & 0.10 & 0.21 & 0.33 & 0.42 & 0.44 & 2.12 & 2.64 & 4.01 \\
\hline $\mathrm{CD}(\overline{\mathrm{P}}=\mathbf{0 . 0 5})$ & 0.69 & 0.73 & 0.90 & 0.86 & 0.58 & 0.68 & 0.42 & 0.78 & 0.61 & 0.15 & 0.21 & 0.13 & 6.42 & 7.98 & 12.14 \\
\hline
\end{tabular}

Table.2 Effect of Panchagavya, Vermiwash and organic manure on reproduction and yield

\begin{tabular}{|c|c|c|c|c|c|c|}
\hline Treatments & Curd diameter $(\mathrm{cm})$ & Curd weight (g) & Curd Initiation (Days) & Curd Maturity (Days) & Yield/plot (kg) & Yield/ha (q) \\
\hline $\mathbf{T}_{1}$ & 9.82 & 616.72 & 69.61 & 81.78 & 9.81 & 228.27 \\
\hline $\mathbf{T}_{2}$ & 8.71 & 582.60 & 68.19 & 79.29 & 9.36 & 215.47 \\
\hline $\mathbf{T}_{3}$ & 10.89 & 655.84 & 66.43 & 78.37 & 10.52 & 242.77 \\
\hline $\mathbf{T}_{4}$ & 10.38 & 635.73 & 65.74 & 77.74 & 10.27 & 235.28 \\
\hline $\mathbf{T}_{5}$ & 11.79 & 724.78 & 65.32 & 76.79 & 11.59 & 267.55 \\
\hline $\mathbf{T}_{6}$ & 12.07 & 737.31 & 63.69 & 74.09 & 11.77 & 273.57 \\
\hline $\mathbf{T}_{7}$ & 9.46 & 598.10 & 64.4 & 75.1 & 9.57 & 221.86 \\
\hline $\mathbf{T}_{8}$ & 11.27 & 699.63 & 67.36 & 79.25 & 11.35 & 259.87 \\
\hline $\mathbf{T}_{9}$ & 6.50 & 455.30 & 70.17 & 82.28 & 7.27 & 168.13 \\
\hline SEm \pm & 0.27 & 1.74 & 0.83 & 1.40 & 0.37 & 1.48 \\
\hline $\mathrm{CD}(\overline{\mathrm{P}}=\mathbf{0 . 0 5})$ & 0.82 & 5.27 & 2.51 & 4.24 & 1.13 & 4.50 \\
\hline
\end{tabular}


Fig.1-8 Graphical representation of effect of Panchagavya, Vermiwash and organic manure on growth, reproductive and yield characters of cauliflower`vc. Pusa Snowball- 2

Fig.- 1

Fig.- 2

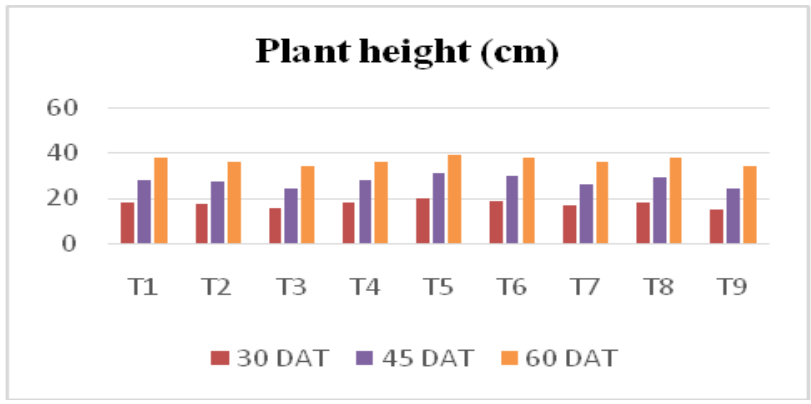

Fig.- 3

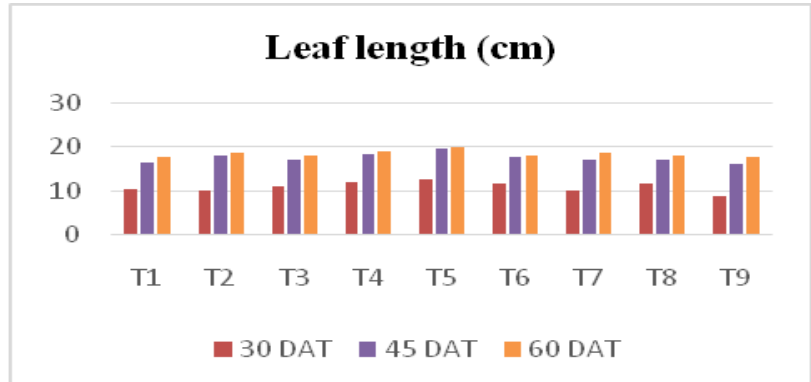

Fig.- 5

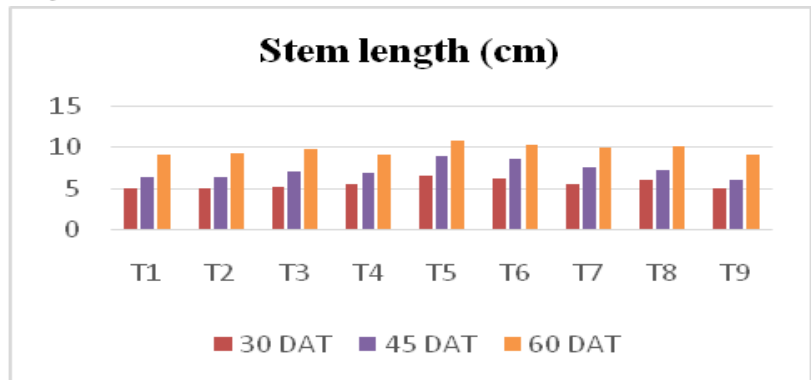

Fig.- 7

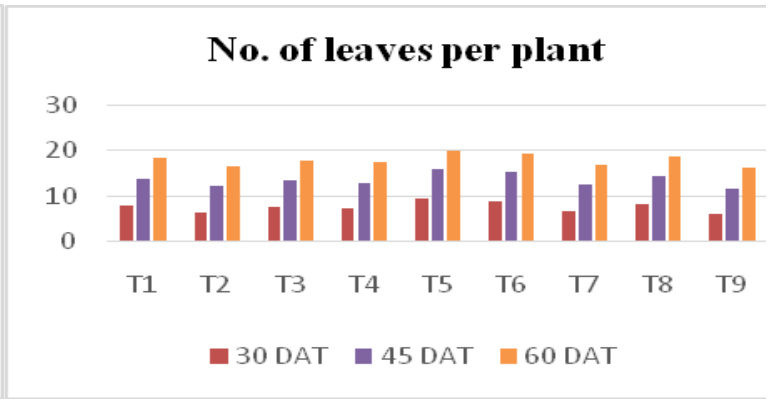

Fig.- 4

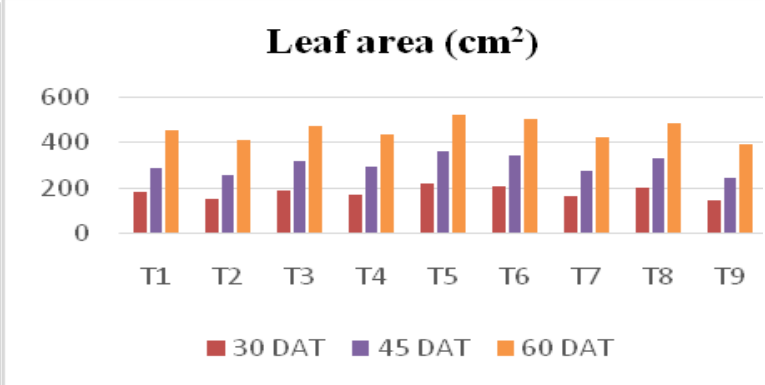

Fig.- 6

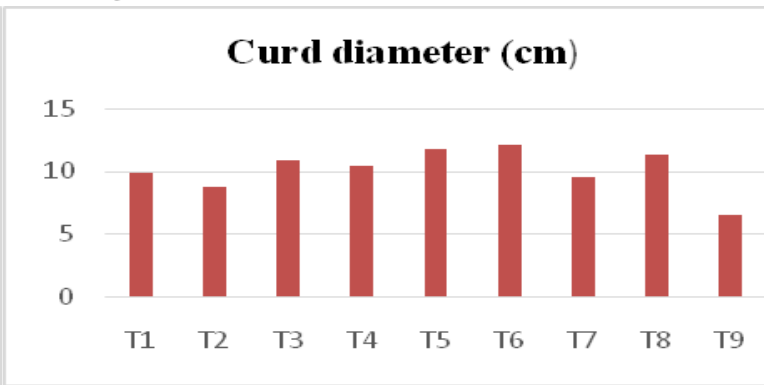

Fig.- 8

Fig.9

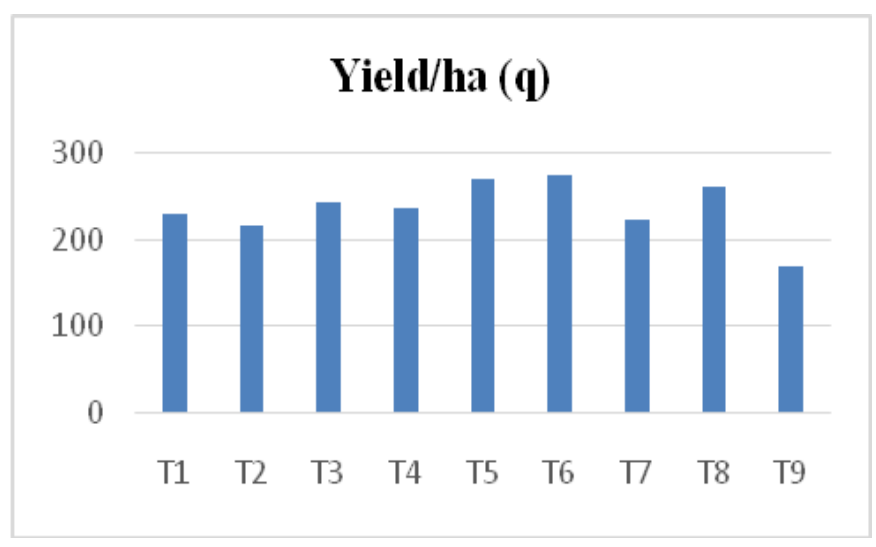


These products act as growth promoter and immunity booster. Panchagavya contains growth regularity substances that helps in the development of Integrated Pest Management (IPM) such as $\mathrm{GA}_{3}$, IAA, Cytokinins, essential plant and organic farming nutrients and effective micro- organisms. This is done due to the production of plant growth substances by Panchagavya which stimulated the metabolic process of plants through the way of activation of desirable enzymes. The above results were enclosed in the findings of Srimathi, S. (2014) investigated the effect of organic nutrient and bio-regulators on growth and yield of cauliflower. Similar kinds of results were also observed by Anburani and Manivannan (2002), Velmurugan (2005), Sanjutha et al., (2008),), Agarkare et al., (2010), Ali et al., (2011) and Gore and Sreenivasa (2011),

Thus, it could be concluded that there are ample variation exist among the different treatments under study which reflects the great opportunity for improving quality as well as quantity in different combinations of Panchagavya, Vermiwash and organic manure in cauliflower. Because of the vegetables produced organically, it fetch higher market price therefore, even if the yield is slightly less with pure organic inputs, it can be recommended for the commercial cauliflower production in view of healthy ecosystem and quality product instead of quantity.

\section{References}

Agarkare, U.R., Dadmal, K.D., Nikas, N.S. and Piwlatkar, G.K. (2010). Effect of nitrogen levels and spacing on growth and yield of broccoli (Brassica oleraceavar. Italic L.). Green Farming, 1(5):477-479.

Ali, M.N., Ghatak, S. and Ragul, T. (2011). Biochemical analysis of Panchagavya and Sanjibani and their effect in crop yield and soil health. Journal of Crop and Weed, 7(2): 84-86.

Anonymous (2018). Horticulture Data base, National Horticulture Board, Ministry of Agriculture and Farmers Welfare, Government of India, Gurugram, Haryana, India.

Anburani, A. and Manivannan, K. (2002). Effect of integrated nutrient management on growth in brinjal (Solanum melongena L.) cv. Annamalai. South Indian Horticulture, 50(4-6): 377-386.

George, S. (2006). Role of vermicompost, vermiwash and other organics in the management of thrips and mites in chilli M.Sc. (Agri.) Thesis, Univ.Agric.Sci., Dharwad, Karnataka, India.

Gomez, K. A. And Gomez, A. A. (1984). Statistical procedure for Agric. Res., 2nd Ed. John Wiley and Sons, New York.

Gore, N.S. and Sreenivasa, M.N. (2011). Influence of liquid organic manures on growth, nutrient content and yield of tomato (Lycopersicon esculentum Mill.) in the sterilized Soil. Karnatka J. Agric.Sci.,24(2): 153-157.

Kanimozhi, B. (2004). Standardization of organic production package of Coleus forskohi. M.Sc. Thesis, Horticultural College and Research Institute, Tamil Nadu Agriculture University, Coimbatore, T.N. (India).

Kanwar, K., Paliyal, S.S. and Nandal, T.R. (2002). Integrated nutrient management in cauliflower (Pusa Snow Ball K-1). Research on Crops, 3: 579-583.

Lalitha, R., Fathima. K. and Ismail, S.A. (2000). The impact of biopesticide and microbial fertilizers on productivity and growth of Abelmoschus esculentus. Vasundara the Earth., (1-2): 4-9.

Mathivanan, R., Edwin, S.C., Viswanathan, K., and Chandrasekaran, D. (2006). 
Chemical, microbial composition and antibacterial activity of modified Panchagavya. International Journal of cow Science, 2(2):42-45.

Natarajan, K. (2002). Panchagavya- A manual. Other India Press, Mapusa, Goa, India. pp: 13-27.

Papen, H., Gabler, A., Zumbusch, E. and Rennenberg, H. (2002). Chemo litho autotrophic nitrifiers in the phyllosphere of a Spruce ecosystem receiving high nitrogen input. Current Microbiology, 44: 56-60.

Sanjutha, S., Subramanian, S., Indu Rani, C. and Maheswari, J. (2008). Integrated nutrient management in Andrographis paniculata. Research Journal of Agriculture and Biological sciences, 4(2):141-145.

Swaminathan, C., Swaminathan, V. and Vijayalakshmi, K. (2007). Panchagavya: Boon to organic farming. International Book, Distributing Co., Lucknow.

Tharmaraj, K., Ganesh, P., Kumar, S.R.,
Anandan, A. and Kolanjinathan, K. (2011b). A critical review on Panchagavya: a boon plant growth. International Journal of Pharmaceutical and Biological Archives, 2(6): 1611-1614.

Velmurugan, M. (2005). Studies on organic farming practices on growth, yield and quality of radish (RaphanussativusL.) cv. Pusa Chetki. South Indian Hort.,53(1-6): 337-339.

Velmurugan, M., Balakrishnamoorthy, G., Rajamani, K., Shanmugasunderam, P. and Gnanam, R. (2008). Effect of organic manures, bio-fertilizers and bio-stimulants on growth and yield of cauliflower (Brassica oleraceavar. botrytis L.) cv. Indam-2435. Crop Research (Hisar), 35(1/2): 42-45.

Yadav, B.K. and Louduraj, C.A. (2006). Effect of organic manures and panchagavya spray on yield attributes and economics of rice (Oryza sativa). Crop Research, 31: 1-5.

\section{How to cite this article:}

Ashok Pal and Shashi Bala. 2020. Influence of Panchagavya, Vermiwash and Organic Manure on Growth and Yield of Cauliflower (Brassica oleracea L. var. botrytis) cv. Pusa Snowball- 2. Int.J.Curr.Microbiol.App.Sci. 9(08): 1373-1379. doi: https://doi.org/10.20546/ijcmas.2020.908.156 